\title{
Prospecting and modeling of primary energy production indicators in Brazil
}

\section{supported by graph theory}

\author{
Prospecção e modelagem de indicadores de produção de energia primária no Brasil com apoio da \\ teoria dos grafos \\ Prospección y modelado de indicadores de producción de energía primaria en Brasil con el apoyo \\ de la teoría de grafos
}

\author{
Mario Mollo Neto \\ ORCID: https://orcid.org/0000-0002-8341-4190 \\ São Paulo State University, Brazil \\ E-mail: mario.mollo@unesp.br \\ Lucélia Maria Casagrande \\ ORCID: https://orcid.org/0000-0002-3209-9207 \\ São Paulo State University, Brazil \\ E-mail: casagrandelucelia@gmail.com \\ Camila Pires Cremasco \\ ORCID: https://orcid.org/0000-0003-2465-1361 \\ São Paulo State University, Brazil \\ E-mail: camila.cremasco@unesp.br \\ Luís Roberto Almeida Gabriel Filho \\ ORCID: https://orcid.org/0000-0002-7269-2806 \\ São Paulo State University, Brazil \\ E-mail: gabriel.filho@unesp.br
}

\begin{abstract}
This research presents a study on the scenario of primary energy production in Brazil over the period from 1970 to 2018, as well as the main sources that contributed to the national energy matrix. To map trends in primary energy production, Social Network Analysis was applied. Also are presented the mathematical models that represent the variation in the centrality and density of primary energy production. Based on the results and the literature on the economy of Brazil in the period between the years 1970 to 2018, it discuss the movements carried out by public policymakers that culminated in a reduction of investments in the sector, even that demand would always be growing. However, it would continue to be linked to the results of small increases in GDP and HDI. Another result was the evolution and of oil as a non-renewable primary source offer for the entire period of the research. Was perceived the alternation of offers from non-renewable sources that, starting with the predominance of firewood, passing on to the generation of hydraulic energy, the most important for two decades, and the substitution by-products derived from sugarcane, which extends until the year 2018. It was also observed that in the period from 2010 to 2018 , the share of supply from renewable primary sources, in percentage terms, it is no longer so distant from the share of offers from non-renewable primary sources, almost even dividing availability for the composition of the Brazilian matrix.
\end{abstract}

Keywords: Primary energy; Graph theory; Ucinet software; SNA.

\section{Resumo}

Esta pesquisa apresenta um estudo sobre o cenário da produção de energia primária no Brasil no período de 1970 a 2018, bem como as principais fontes que contribuíram para a matriz energética nacional. Para mapear as tendências na produção de energia primária, foi aplicada a Análise de Redes Sociais. Também são apresentados os modelos matemáticos que representam a variação na centralidade e densidade da produção de energia primária. Com base nos resultados e na literatura sobre a economia do Brasil no período de 1970 a 2018, discutem-se os movimentos realizados pelos formuladores de políticas públicas que culminaram na redução dos investimentos no setor, mesmo que a demanda fosse sempre crescente. No entanto, continuaria associado aos resultados de pequenos aumentos do PIB e do IDH. Outro resultado foi a evolução e oferta do petróleo como fonte primária não renovável para todo o período da pesquisa. Percebeu-se a alternância de ofertas de fontes não renováveis que, partindo do predomínio da lenha, passando para a geração de energia hidráulica, a mais importante durante duas décadas, e a substituição de subprodutos derivados da cana-de-açúcar, que se estende até a ano 2018. Observou-se também que no período de 2010 a 2018, a participação da oferta por fontes primárias renováveis, em termos percentuais, deixou de se distanciar 
da participação das ofertas por fontes primárias não renováveis, quase até se dividindo a disponibilidade para a composição da matriz brasileira.

Palavras-chave: Energia primária; Teoria dos grafos; Software ucinet; SNA.

\begin{abstract}
Resumen
Esta investigación presenta un estudio sobre el escenario de producción de energía primaria en Brasil de 1970 a 2018 , así como las principales fuentes que contribuyeron a la matriz energética nacional. Para mapear tendencias en la producción de energía primaria, se aplicó el Análisis de Redes Sociales. También se presentan modelos matemáticos que representan la variación en la centralidad y densidad de la producción de energía primaria. Con base en los resultados y en la literatura sobre la economía brasileña en el período de 1970 a 2018, se discuten movimientos realizados por los hacedores de políticas públicas que culminaron en la reducción de las inversiones en el sector, aunque la demanda siempre fue en crecimiento. Sin embargo, permanecería asociado a los resultados de pequeños incrementos del PIB y del IDH. Otro resultado fue la evolución y el suministro de petróleo como fuente primaria no renovable durante todo el período de investigación. Se notó la alternancia de ofertas de fuentes no renovables, a partir del predominio de la leña, pasando a la generación de energía hidráulica, la más importante desde hace dos décadas, y la sustitución de subproductos derivados de la caña de azúcar, que se extiende hasta el año 2018. También se observó que en el período de 2010 a 2018, la participación de la oferta por fuentes primarias renovables, en términos porcentuales, ya no se alejó de la participación de la oferta por fuentes primarias no renovables, casi incluso dividiendo la disponibilidad para la composición de la matriz brasileña.
\end{abstract}

Palabras clave: Energía primaria; Teoría de grafos; Software ucinet; SNA.

\title{
1. Introduction
}

Regarding the world scenario, the demand for primary energy increased by $2.2 \%$ in 2018 , the fastest growth since 2013. In the same year, electricity generation grew by $2.8 \%$, with $94 \%$ of this growth coming from emerging economies. In addition, the global demand for energy is above the 10-year average, according to British Petroleum (BP) statistical analysis, on world energy 2018 (British Petroleum, 2018).

With regard to the national scope, Brazil is currently at a time of economic downturn, slowing the demand for primary energy, which grew $1.3 \%$ less than the average of $2.5 \%$ in the last ten years (Silveira, 2019). However, it is necessary that the country invest adequately in renewable energies, considering the forecast of expansion of energy demand when the economy resumes growth. Thus, Firjan - Federation of Industries of the State of Rio de Janeiro - estimates that the demand for energy will grow by $2.2 \%$ per year in addition to the world average, and will correspond to $3 \%$ of global primary energy in 2040 (Firjan, 2019).

Although considered a privileged country for its variety in renewable energy sources, energy efficiency and essential technologies, they need a boost in Brazil to respond to different types of demand (EPE, 2018). In addition, public policymakers may find it difficult to target investments effectively to meet the growing energy demand, in a context that seeks to produce more with less energy (Ren 21, 2019). Therefore, considering the context of projections for growth in demand for primary energy, the need to invest in renewable energies to diversify the energy matrix and motivated by the national experience of investments in the energy sector. Thus, the interest in studying the national history of primary energy production, which is the central theme of the research, is justified.

In the context of movements in the energy sector, the decisions of public policymakers are of major influence on the ideal evolution of the energy matrix, thus, despite the Brazilian historical experiences, the graph theory was applied to facilitate understanding, through modeling mathematics, of the relations between Brazil and the various sources of energy. Graph theory is applied computationally to facilitate the understanding of a social network, which is a simple way, is defined as a set of individuals with dependency connections among themselves (Nascimento, 2013).

This research sought to prepare a study on the scenario of the behavior of primary energy production in Brazil over the period from 1970 to 2018 , as well as the exchanges that occurred between the main sources that collaborated for the 
national energy matrix over the years, identifying the highlights of these changes and the mathematical modeling of this behavior.

In this work, the objectives were to i) carry out a survey of the total primary energy generated in the country within the period from 1970 to 2018; ii) build the corresponding relational matrices and structural indicators of centrality and density of the primary energy supply; iii) build the graphs for each of the years of the study period obtained with the Ucinet Netdraw visualization tool; iv) determine the mathematical models of the variation of centralities and densities and; v) discuss the movements carried out by public policymakers over these decades based on data and experience from the national scene.

According to Demirel (2012), primary energy is extracted or captured directly from the environment, while secondary energy is converted from primary energy in the form of electricity or fuel.

As examples of primary energy sources Demirel (2012) says that we have two main groups: i) non-renewable energy (fossil fuels): coal, crude oil, natural gas, nuclear fuel; ii) renewable energy: hydroelectric energy, biomass, solar energy, wind, geothermal and ocean energy.

According to the report of the National Energy Balance - BEN, in the scenario of the national energy matrix, the internal supply of primary energy is predominantly composed of oil, derivatives of cane and hydraulics. Regarding Secondary sources, Demirel (2012) mentions that primary energy is transformed into secondary energy in the form of electricity or fuel, such as gasoline, fuel oil, methanol, ethanol, and hydrogen. Primary energy from renewable energy sources, such as the sun, wind, biomass, geothermal energy and fluid water is generally equated with the electrical or thermal energy produced from them.

The energy available in 2018 in Brazil was 288.4 Mtoe (millions of tons of oil equivalent), corresponding to a decrease of $1.7 \%$ in relation to 2017 , with respect to electricity, there was a growth of 10.7 TWh (terawatt- hour) and $4.1 \%$ of available hydraulic energy (BEN, 2019).

It is well known that societies, richer, more populous and more complex, demand greater energy demands. Such societies have evolved by accessing progressively larger energy flows and cannot be sustained in the absence of these flows (Tainter, 2011).

Energy consumption is one of the main factors of economic development and the level of quality of life in any society. It reflects both the pace of activity in the industrial, commercial and service sectors, as well as the population's ability to acquire technologically more advanced goods and services, such as automobiles (which require fuel), appliances and electronics that require access to the power grid and pressure the electric energy consumption (EPE, 2018).

The growth of the world population and the increase in energy per capita means that global energy consumption continues its positive trend, increasing by around 2.3\% in 2012-2013. The rate of population growth has slowed in the industrialized countries, but economic development in these countries drives an increasing need for energy (Sorrell, 2015). However, Brazil has always had a low per capita energy consumption. The growth of national income and its redistribution should cause this consumption to increase.

Estimates for 2030 show a primary energy consumption of about 560 million toe (tons of oil equivalent) for a population of more than 238 million inhabitants. Under these conditions, per capita, demand would increase from 1,190 to 2,345 toe / $10^{3}$ inhabitants. between 2005 and 2030 (Tolmasquim et al. 2007).

Historically, Brazil has an important comparative advantage in the energy sector related to the abundance of natural resources and is in a favorable position when it comes to the use of renewable energy sources. However, the country's socioeconomic development will result in greater use of energy, which is not guaranteed to come exclusively from renewable sources (Nogueira et al., 2014). 
Studies relating energy consumption and Gross Domestic Product are vast in the literature, however, most of them analyze countries in isolation, making their interpretation and generalization difficult, since each country differs in its economy and technology. In addition, there are arguments based on the assumption that economic growth increases energy demand or the increase in energy consumption stimulates economic growth (Mahalingam \& Orman, 2018). Although there is no consensus among researchers on the relationship between economy and GDP, electricity and energy consumption are essential tools for nations to improve technologies, increase the population's standard of living and stimulate scientific development, therefore many researchers consider the consumption of electricity as an important economic indicator (Ouedraogo, 2013).

In Brazil, according to the BIG - Generation Information Bank (BIG), there are 163,790,982 kW of installed power, $60.19 \%$ of which is hydroelectric and $24.69 \%$ are thermoelectric. The forecasts indicate that $19,576,784 \mathrm{~kW}$ will be complemented by the Brazilian electric generation capacity since, although the country is at an economically uncertain time, the growing demand for electricity is notable (ANEEL, 2019).

Considering social and environmental issues, there is a growing need to diversify the world energy matrix. In this regard, Brazil has the potential to explore renewable energies. According to the Generation Information Bank, in the current context, there are 58 projects with construction started for the exploitation of wind energy and 18 for the exploitation of photovoltaic energy (ANEEL, 2019).

According to the Electric Energy Atlas of Brazil, nationally, the country also has potential for wind power generation, mainly in the coastal region of the North and Northeast, and the wind volume is twice the world average, in addition, the oscillation of the winds is around 5\%, facilitating the generation estimate (ANEEL, 2008).

In relation to the other sources that make up the Brazilian energy matrix, thermoelectric plants correspond to $1.35 \%$ of the enterprises in operation in Brazil with an associated power of $2,253,498 \mathrm{KW}$, compared to the national scenario, thermoelectric plants are not very significant (ANEEL, 2019).

The proposed tool in this research was the Graph theory, originated with the researcher Leonhard Euler in the year 1735 with the famous Königsberg Bridges Problem, culminating in highly regular graphs, and in the 90s, ramifications of graph theory appeared, such as Random Graph Theory and Algebraic Graph Theory (Dehmer et al. 2017). There are also the ramifications of graph theory called, Spectral Graph Theory, Topological Graph Theory, and Quantitative Graph Theory. Quantitative graph theory is defined as a measurement method to quantify networks (Dehmer et al. 2017).

In the studies carried out by Dehmer et al. (2017), the authors highlight that the Quantitative Graph Theory was defined as a measurement approach to quantify the structural information of the networks. In general, local, global or comparative graphical measures can be used to measure structural information. It is emphasized that this definition complements the graph theory (classical), which deals mainly with the description of the structural properties of graphs.

The domain of knowledge in an increasingly technological, complex and competitive world is not limited to individuals or organizations, therefore, to stay in development it is vital to connect in systemic networks where the actors' influence and are influenced in the context considered. These networks can be formal or informal and researched from various perspectives, one of which is the social network analysis, SNA (Mollo Neto, 2015).

In a social environment, understanding the relationships, the flow of sharing ideas between agents and how each person's position influences access to knowledge and resources, such as assets and capital, helps strategic planning and drives collaboration between actors, generating advantageous results for the network (Mollo Neto et al., 2010).

In Stokman's (2001) perspective, the global structure of a social network is the cause and result of the individual actions of each element of the network, which cultivate a pattern of behavior, expanding or limiting opportunities for access to resources so that its individuals accomplish your goals. 
For Peng et al. (2018), social network analysis is the representation of the flow and relationships between connected information, research and knowledge entities, groups and organizations.

According to Rossoni et al. (2008), the actors in a social network are the objects of study that can be represented by countries, institutions, and organizations.

In this context, Izquierdo; Hanneman (2006), added that the centrality in a network indicates the power of influence to disseminate information among its actors and for Tomaél \& Marteleto (2006), it is the measurement of direct contacts that an actor has in the network.

In Hanneman's conception; Riddle (2005), if an actor receives many calls directed to him, it means that he is a prestigious and influential actor in the network.

The determination of centralities according to the Emirbayer \& Goodwin (1994), integrated into the software application, which calculates the degree of centrality, is calculated according to Equation 1:

\section{$C g\left(V_{k)}=\sum_{j=1}^{n} w_{K J}\right.$}

Eq. 1

Where: $C_{g}=$ Degree of Centrality; $V_{k}=$ Network node to be considered; $j=$ Number of nodes;

$W_{K f}=$ The number of adjacent nodes; $W_{K J=1}$ if there is a link between the nodes $v k$ and $v j$.

Density is a structural indicator aimed at the degree of connection between the actors; its quantification is determined by the ratio of the number of links between actors in the network, over the total possible links in the studied network (Masquietto et al. 2011). Mathematically the definition of density by Levine \& Kurzban (2006) is represented by Equation 2:

\section{$\Delta=2 \mathbf{R} \mathbf{l}(\mathbf{l}-1)$}

Eq. 2

Where: $\mathrm{R}=$ the number of relationships in the network and $\mathrm{I}=$ the number of actors that make up the network.

Research related to the social network includes a variety of data such as institutions, individuals, countries, and organizations, which interact with each other for different reasons. For the treatment of structural data in a network to be represented properly, the use of the software is necessary (Carley et al., 2007). According to Makagon et al. (2012) there are several software tools developed for the processing of structural information from social networks, allowing their analysis with objective data, the structural visualization of graphs and facilitating the calculation of their statistical metrics.

The choice of software must be made based on the knowledge of its main characteristics and resources, in addition to the needs of the studied network, Mollo Neto (2015), highlighted the Ucinet program and the NetDraw module as one of the most common tools for analyzing social networks. Developed by Borgatti; Everett \& Freeman (2002) at the University of California at Irvine and marketed by Analytic Technologies, the software works matrix data network together with the Net Draw software, used to create graphs and diagrams facilitating the visual analysis of the studied social network.

According to Scott (1996), Ucinet software is the most suitable for researchers who are starting work with social networks.

In Bassanezi (2002) view, mathematical modeling through numerical representations such as algebraic equations or inequalities seeks to reflect reality and helps decision making by trying to understand fundamental parameters of some object of study and transforming them into an artificial system.

According to Daniel (2016), "Given the sequence of real numbers $(a 0, a 1, a 2, \ldots$, an) consider the function $P: \mathrm{R} \rightarrow$ R, given by Equation 3: 


\section{$\mathbf{P}(\mathbf{x})=\mathbf{a n x n}+\mathbf{a n}-1 \times n-1+\ldots+\mathbf{a} 2 \times 2+\mathbf{a} 1 \mathbf{x}+\mathbf{a 0} \quad$ Eq. 3}

The polynomial function can be obtained from a graph constructed with the Excel tool and using the functionality of obtaining the regression equation and the respective degree of error attributed to the equation, known as the coefficient of determination $\left(\mathrm{R}^{2}\right)$ (Souza, 2018).

According to Mollo Neto et al. (2014) the coefficient of determination $\mathrm{R}^{2}$ (Equation 4), is a descriptive measure used to verify the degree of explanation of the $\mathrm{Y}$ variation, and the closer to 1, it indicates the best adjustment of Equation 4 elaborated based on (CONWAY, 1962).

When the value of $\mathrm{R}^{2}$ is equal to 1 (one) it indicates an exact fit of the model for the measured data of the process" (Mollo Neto et al., 2014).

$$
\left[R^{2}\right]=\frac{\sum_{h}^{n}=1[y(k)-s(k)]^{2}}{\sum_{h}^{n}=1[y(k)-s]^{2}}
$$

Where: $y(k)$ is the real output, $z(k)$ is the estimated output, it is the average of the $N$ samples of the experiment.

\section{Methodology}

To achieve the objectives of this work, a quantitative style and descriptive documentary research were carried out. The classification of the research was based on (Creswell, 2007).

The research regarding its quantitative characteristics, deals with the hypotheses as described by Koche (2011), who states that they would result from the inductive process of the meticulous observation of the existing quantitative relationships between the facts and the resulting scientific knowledge, would be formed by the proven certainties by the experimental evidence of some analyzed cases.

Still taking into account the provisions of Koche (2011), regarding the descriptive, non-experimental, or ex post facto research that was carried out for this work, he studied the relationships between the phenomenon's variables without manipulating them, verifying and evaluating these relationships as these variables manifested spontaneously in the conditions that already exist over the years of the study carried out.

The research technique adopted in this case, as indicated by Pereira et al. (2018), was the technique of searching for documents: files, statistical records, diaries, biographies, newspapers, magazines, among others, that could help in the research.

This technique can also be called file analysis strategy, as indicated in the work of Yin (2015).

According to the work of Ludke \& Andre (2013), documents are also a powerful source from which evidence supporting the researcher's assertions and statements can be taken, and they represent a "natural" source of information with the advantage of having low cost. Another advantage of documents, according to the same authors, is that they are a nonreactive source, allowing data to be obtained when access to the subject is impractical or when interaction with subjects can change their behavior or their points of view.

The survey was conducted with data on the production of primary energy supply in Brazil, including renewable and non-renewable energy from 1970 to 2018, data made available and updated annually by the Energy Research Company (EPE, 2018). Through the citizen information service, it was possible to access the information. After collecting and organizing the data year by year, the Social Network Analysis and Graph Theory tool was applied to understand the evolution of investments in the energy sector in Brazil.

The research is classified as a descriptive study since it describes the distribution of the types of an internal source of 
primary energy in Brazil, as well as the perceptions of historical evolution and, identifies ideas or patterns related to the investments made in the energy sector. The research is also documentary, as it uses official EPE documents, containing numerical data since 1970 .

\section{Data processing}

From the data collected and tabulated in Microsoft Excel spreadsheets, the research took place in two distinct phases: In the first phase, the data were used to build visual network analysis (VNA) database files that make it possible to process the data with use of the Ucinet tool software, according to the method described in the documentation generated by (Borgatti et al., 2002).

The Ucinet 6 for Windows software, which is normally used for the analysis of egocentric or socio-centric social networks in different contexts and calculates different network measurements, generating graphs to visualize network interactions with the integrated tool Net Draw version 2.160, which integrates the software (Borgatti et al., 2002).

The processing of this database allowed the achievement of structural indicators "centrality", "degree centrality" and "density".

Through the centrality, the primary source of energy actor that had the greatest influence in each year and its change over the historical period studied was identified. The network densities allowed visualizing the development of the sources and their contribution to Brazil in the studied period. The indicators were selected and tabulated, year by year from 1970 until 2018. From these indicators, graphs of densities and indegree were drawn up in the same terms proposed by (Mollo Neto, 2014).

From these graphs of densities and degrees of the centrality of entry, according to the recommendations of the same author, trend lines corresponding to indicators using Excel were obtained. With these in mind, the equations of the mathematical models that represent them in the form of polynomials or polynomial functions were built, as well as the corresponding determination coefficients.

After the construction of the mathematical models and the coefficients of determination, we sought to visually identify in the graphs, mainly in what represents the centralities, the most prominent points, which were the basis for the discussions seeking to correlate the periods of growth and fall of the centralities with social, political and mainly economic events of the period covered.

Afterward, a new round of searches in the bibliographies was carried out to find the socio-political and economic movements that occurred at the moments highlighted in the graph generated with the centralities.

In the case of the density graph, we sought to verify the growth of the function obtained with the growth in demand for primary energy, in the country and whether it followed, even if with a different degree of slope, the growth trend of GDP and the HDI of the country for the same period.

\section{Results and Discussion}

Initially, from the collection of data obtained from the prospecting of Energy Research Company reports, (EPE, 2018) Tables 1 to 5 were constructed representing the energy supply in the period from 1970 to 2018.

For the presentation, the collection tables were organized in periods of ten years each, so a better visualization is guaranteed. Thus, Table 1 comprises the period of data collection from 1970 to 1979, Table 2 comprises the period from 1980 to 1989 , Table 3 comprises the period from 1990 to 1999, Table 4 comprises the period from 2000 to 2009 and Table 5 comprises the period from 2010 to 2018 .

The tables initially show the non-renewable sources and then the renewable sources, in which it is possible to observe 
the reduction in the use of more aggressive energies to the environment and the increase in the use of renewable and cleaner energies.

In Table 1, Firewood stands out as the main source for the entire period, a renewable but not sustainable source. It is also observed that, in this period, there is a proportion of approximately $20.8 \%$ of production from non-renewable sources and $79.2 \%$ from renewable sources.

During this period there was no nuclear energy production, since uranium source, despite having the facilities available, did not present production in the entire period. The same was observed for wind or solar energy sources; however, even installed infrastructure was not available.

The oil source, in this period, represented the amount of approximately $13.6 \%$ and the generation of hydraulic energy was slightly higher, around $16.1 \%$ of the total.

The total energy supply in Brazil in this period grew by $25.14 \%$.

In Table 2, it also stands out as the main source for the entire period, Firewood, a renewable but not sustainable source. It is also observed that, in this period, the proportion varied from approximately $21.17 \%$ in 1980 to $36.21 \%$ in 1989 of production from non-renewable sources and from $78.83 \%$ in 1980 and $63.79 \%$ in 1989 from sources renewable.

The oil source, in this period, represented the amount of approximately $27.6 \%$ and the generation of hydraulic energy was slightly higher, around $15.85 \%$ of the total.

The total energy supply in Brazil in this period grew by $67.1 \%$. During this period, there was the production neither wind or solar energy. The production of nuclear energy (uranium) increased with the production of $3.78 \%$ of the total in 1982, but it declined to a share of only $0.31 \%$ at the end of 1989 .

Renewable sources, also, in this decade, were superior in production compared to non-renewable ones.

Table 3 shows a more predominant source change, and Petroleum, a non-renewable source, which is aggressive to the environment, stands out for the entire period.

It is also observed that, in this period, the proportion varied from approximately $38.20 \%$ in 1990 to $48.61 \%$ in 1999 of production from non-renewable sources and from $61.80 \%$ in 1980 and $51.39 \%$ in 1989 from renewable sources.

Renewable sources, also, in this decade, were superior in production compared to non-renewable ones. The oil source, in this period, represented the amount of approximately $38.66 \%$ and the generation of hydraulic energy was lower, around $17.20 \%$ of the total.

The total energy supply in Brazil in this period grew by 35.95\%. In this period, there was also no production of wind or solar energy.

The production of nuclear energy (Uranium), however, only produced $0.04 \%$ of the total in 1990, and in 1998 only $0.01 \%$ at the end of 1999 , with no production at all remainder of the period.

In Table 4, the most prevalent source remains, and Petroleum is a prominent source for the entire period, which is non-renewable and aggressive to the environment.

It is also observed that, in this period, the proportion varied from approximately $52.66 \%$ in 2000 to $53.79 \%$ in 2009 of production from non-renewable sources and from $47.34 \%$ in 2000 and $46.21 \%$ in 2009 from sources renewable.

The oil source, in this period, represented the amount of approximately $41.96 \%$ and the generation of hydraulic energy was lower, around $13.98 \%$ of the total.

The total energy supply in Brazil in this period grew by 56.68\%. In this period, there was also no production of solar energy.

Wind energy started to start production and the first infrastructure for generation and distribution was made available, is a new clean and renewable source in 2001 with the production of $0.002 \%$ of the total generated in the country. 
The production of nuclear energy (Uranium), in 2000, produced $0.08 \%$ of the total in 2000, and in 2009, with a significant improvement, reaching a value of $1.71 \%$.

Renewable sources, in this decade, proved to be inferior in production compared to non-renewable ones, which may indicate a warning signal, which points to the need to search for the urgent implementation of renewable sources that can replace non-renewable ones in order to guarantee sustainability to the national matrix.

In Table 5, the most prevalent source remains, and Petroleum is a prominent source for the entire period, which is non-renewable. It is also noted that, in this period, the proportion varied from approximately $53.03 \%$ in 2010 to $58.17 \%$ in 2018 of non-renewable sources production and from $46.97 \%$ in 2010 and $41.83 \%$ in 2018 from sources renewable. The source of oil, in this period, represented the amount of approximately $43.70 \%$ and the generation of hydraulic energy was lower, around $10.90 \%$ of the total 
Research, Society and Development, v. 10, n. 10, e485101019199, 2021

(CC BY 4.0) | ISSN 2525-3409 | DOI: http://dx.doi.org/10.33448/rsd-v10i10.19199

Table 1- Primary energy production in Brazil 1970-1979.

$10^{3}$ tep (toe)

\begin{tabular}{|c|c|c|c|c|c|c|c|c|c|c|}
\hline SOURCES & 1970 & 1971 & 1972 & 1973 & 1974 & 1975 & 1976 & 1977 & 1978 & 1979 \\
\hline Non-renewable & 10.590 & 10.934 & 10.802 & 10.809 & 12.063 & 11.694 & 11.759 & 11.890 & 12.223 & 12.714 \\
\hline Petroleum & 8.161 & 8.521 & 8.313 & 8.453 & 8.969 & 8.727 & 8.473 & 8.177 & 8.154 & 8.419 \\
\hline Natural gas & 1.255 & 1.169 & 1.232 & 1.171 & 1.477 & 1.613 & 1.630 & 1.795 & 1.919 & 1.885 \\
\hline Steam coal & 611 & 654 & 657 & 600 & 830 & 743 & 951 & 1.095 & 1.250 & 1.404 \\
\hline Metallurgical coal & 504 & 533 & 537 & 529 & 730 & 558 & 643 & 769 & 845 & 923 \\
\hline Uranium (u308) & 0 & 0 & 0 & 0 & 0 & 0 & 0 & 0 & 0 & 0 \\
\hline Other non-renewable & 60 & 57 & 63 & 55 & 57 & 53 & 62 & 53 & 55 & 83 \\
\hline Renewable & 39.037 & 39.538 & 41.037 & 41.774 & 43.155 & 43.857 & 44.107 & 45.814 & 46.454 & 49.389 \\
\hline Hydraulic energy & 3.422 & 3.714 & 4.357 & 4.977 & 5.646 & 6.214 & 7.128 & 8.036 & 8.833 & 10.022 \\
\hline Firewood & 31.852 & 31.807 & 32.143 & 31.897 & 32.599 & 33.154 & 31.882 & 30.822 & 29.794 & 30.375 \\
\hline Sugarcane products & 3.601 & 3.842 & 4.298 & 4.644 & 4.619 & 4.180 & 4.748 & 6.539 & 7.322 & 8.254 \\
\hline Wind energy & - & - & - & - & - & - & - & - & - & - \\
\hline Solar energy & - & - & - & - & - & - & - & - & - & - \\
\hline Other Renewables & 163 & 176 & 238 & 256 & 292 & 310 & 350 & 417 & 506 & 739 \\
\hline Total & 49.627 & 50.472 & 51.839 & 52.583 & 55.219 & 55.552 & 55.866 & 57.704 & 58.678 & 62.103 \\
\hline
\end{tabular}

Source: EPE (2018) 
Table 2 - Primary energy production in Brazil 1980-1989

$10^{3}$ tep (toe)

\begin{tabular}{|c|c|c|c|c|c|c|c|c|c|c|}
\hline SOURCES & 1980 & 1981 & 1982 & 1983 & 1984 & 1985 & 1986 & 1987 & 1988 & 1989 \\
\hline Non-renewable & 14.058 & 16.240 & 22.411 & 26.537 & 33.789 & 38.267 & 39.044 & 39.327 & 38.262 & 40.178 \\
\hline Petroleum & 9.256 & 10.928 & 13.338 & 16.911 & 23.712 & 28.080 & 29.433 & 29.104 & 28.448 & 30.623 \\
\hline Natural gas & 2.189 & 2.457 & 3.008 & 3.983 & 4.866 & 5.427 & 5.644 & 5.738 & 6.005 & 6.060 \\
\hline Steam coal & 1.493 & 1.922 & 2.194 & 2.355 & 2.657 & 2.620 & 2.491 & 2.377 & 2.492 & 2.221 \\
\hline Metallurgical coal & 991 & 726 & 731 & 751 & 836 & 903 & 854 & 636 & 789 & 675 \\
\hline Uranium (u308) & 0 & 0 & 2.900 & 2.312 & 1.399 & 1.011 & 365 & 1.151 & 183 & 355 \\
\hline Other non-renewable & 129 & 206 & 241 & 224 & 320 & 227 & 258 & 320 & 345 & 244 \\
\hline Renewable & 52.347 & 52.741 & 54.309 & 59.680 & 65.559 & 68.723 & 67.216 & 71.045 & 70.368 & $\mathbf{7 0 . 7 8 3}$ \\
\hline Hydraulic energy & 11.082 & 11.241 & 12.132 & 13.022 & 14.321 & 15.334 & 15.682 & 15.955 & 17.115 & 17.596 \\
\hline Firewood & 31.083 & 30.415 & 29.109 & 30.233 & 33.340 & 32.925 & 32.766 & 32.777 & 32.565 & 32.953 \\
\hline Sugarcane products & 9.301 & 10.196 & 12.140 & 15.455 & 16.793 & 19.108 & 17.257 & 20.772 & 19.032 & 18.480 \\
\hline Wind energy & - & - & - & - & - & - & - & - & - & - \\
\hline Solar energy & - & - & - & - & - & - & - & - & - & - \\
\hline Other Renewables & 881 & 888 & 928 & 970 & 1.105 & 1.356 & 1.512 & 1.542 & 1.657 & 1.754 \\
\hline Total & 66.404 & 68.981 & 76.721 & 86.217 & 99.348 & 106.990 & 106.261 & 110.372 & 108.630 & 110.961 \\
\hline
\end{tabular}

Source: EPE (2018). 
Table 3 - Primary energy production in Brazil 1990-1999.

$10^{3}$ tep (toe)

\begin{tabular}{|c|c|c|c|c|c|c|c|c|c|c|}
\hline SOURCES & 1990 & 1991 & 1992 & 1993 & 1994 & 1995 & 1996 & 1997 & 1998 & 1999 \\
\hline Non-renewable & 41.139 & 41.189 & 41.674 & 42.713 & 44.481 & 46.022 & 51.789 & 55.917 & 63.754 & 71.184 \\
\hline Petroleum & 32.550 & 32.117 & 32.466 & 33.169 & 34.446 & 35.776 & 40.521 & 43.590 & 50.512 & 56.612 \\
\hline Natural gas & 6.233 & 6.548 & 6.924 & 7.301 & 7.699 & 7.896 & 9.088 & 9.752 & 10.708 & 11.810 \\
\hline Steam coal & 1.595 & 1.954 & 1.794 & 1.784 & 1.943 & 1.967 & 1.792 & 2.111 & 2.067 & 2.110 \\
\hline Metallurgical coal & 320 & 147 & 81 & 37 & 76 & 68 & 85 & 58 & 13 & 19 \\
\hline Uranium (u308) & 51 & 0 & 0 & 0 & 0 & 0 & 0 & 0 & 23 & 0 \\
\hline Other non-renewable & 391 & 422 & 407 & 422 & 317 & 315 & 302 & 406 & 431 & 633 \\
\hline Renewable & 66.551 & 67.498 & 66.691 & 66.951 & 70.419 & 69.475 & 71.000 & 74.461 & 74.491 & 75.226 \\
\hline Hydraulic energy & 17.770 & 18.722 & 19.200 & 20.208 & 20.864 & 21.827 & 22.847 & 23.982 & 25.056 & 25.188 \\
\hline Firewood & 28.537 & 26.701 & 25.089 & 24.803 & 24.858 & 23.261 & 21.969 & 21.663 & 21.261 & 22.126 \\
\hline Sugarcane products & 18.451 & 20.093 & 20.064 & 19.378 & 22.010 & 21.778 & 23.397 & 25.939 & 25.155 & 24.575 \\
\hline Wind energy & - & - & - & - & - & - & 0 & 0 & 0 & 0 \\
\hline Solar energy & - & - & - & - & - & - & - & - & - & - \\
\hline Other Renewables & 1.793 & 1.982 & 2.338 & 2.562 & 2.688 & 2.608 & 2.786 & 2.877 & 3.019 & 3.337 \\
\hline Total & 107.690 & 108.688 & 108.365 & 109.663 & 114.900 & 115.497 & 122.789 & 130.378 & 138.245 & 146.411 \\
\hline
\end{tabular}


Table 4 - Primary energy production in Brazil 2000-2009

$10^{3}$ tep (toe)

\begin{tabular}{|c|c|c|c|c|c|c|c|c|c|c|}
\hline SOURCES & 2000 & 2001 & 2002 & 2003 & 2004 & 2005 & 2006 & 2007 & 2008 & 2009 \\
\hline Non-renewable & 80.756 & 84.561 & 96.783 & 98.616 & 100.350 & 106.867 & 112.636 & 116.084 & 123.161 & 129.340 \\
\hline Petroleum & 63.849 & 66.742 & 74.927 & 77.225 & 76.641 & 84.300 & 89.214 & 90.765 & 94.000 & 100.918 \\
\hline Natural gas & 13.185 & 13.894 & 15.416 & 15.681 & 16.852 & 17.575 & 17.582 & 18.025 & 21.398 & 20.983 \\
\hline Steam coal & 2.603 & 2.175 & 1.936 & 1.785 & 2.016 & 2.348 & 2.200 & 2.257 & 2.552 & 1.913 \\
\hline Metallurgical coal & 10 & 10 & 63 & 38 & 137 & 135 & 87 & 92 & 101 & 167 \\
\hline Uranium (u308) & 132 & 669 & 3.335 & 2.745 & 3.569 & 1.309 & 2.338 & 3.622 & 3.950 & 4.117 \\
\hline Other non-renewable & 978 & 1.071 & 1.106 & 1.142 & 1.134 & 1.200 & 1.214 & 1.323 & 1.159 & 1.242 \\
\hline Renewable & 72.577 & 71.826 & 77.477 & 85.126 & 89.888 & 93.655 & 99.166 & 107.624 & 113.394 & 111.118 \\
\hline Hydraulic energy & 26.168 & 23.028 & 24.604 & 26.283 & 27.589 & 29.021 & 29.997 & 32.165 & 31.782 & 33.625 \\
\hline Firewood & 23.054 & 22.437 & 23.645 & 25.965 & 28.187 & 28.420 & 28.496 & 28.618 & 29.227 & 24.609 \\
\hline Sugarcane products & 19.895 & 22.800 & 25.279 & 28.357 & 29.385 & 31.094 & 35.133 & 40.458 & 45.019 & 44.775 \\
\hline Wind energy & 0 & 3 & 5 & 5 & 5 & 8 & 20 & 57 & 102 & 106 \\
\hline Solar energy & - & - & - & - & - & - & - & - & - & - \\
\hline Other Renewables & 3.460 & 3.557 & 3.944 & 4.516 & 4.721 & 5.112 & 5.519 & 6.325 & 7.265 & 8.002 \\
\hline Total & 153.334 & 156.386 & 174.260 & 183.742 & 190.238 & 200.522 & 211.802 & 223.708 & 236.555 & 240.458 \\
\hline
\end{tabular}

Source: EPE (2018) 
The total energy supply in Brazil in this period grew by $21.1 \%$. During this period, the production of solar energy begins. In 2015 it is observed that production was equivalent to $0.0017 \%$ of the total and in 2018 it reached $0.097 \%$ of the total.

Wind energy from renewable and clean sources in 2010 contributed to the production of $0.074 \%$ of the total generated in the country and ended in 2018 with a contribution of $1.36 \%$.

The production of nuclear energy (Uranium), in 2010, produced $0.70 \%$ of the total in 2000, and in 2015 it dropped significantly to $0.18 \%$ and after that, until the end of the year 2018 , no more production was registered.

As a highlight, still in this Table 6, it is observed that the use of metallurgical coal, as an energy source, disappeared in 2010 and there were no more records on this source until the end of 2018. Again, in this decade, the sources of nonrenewable resources outnumbered renewable ones.

During the studied decades, it was possible to identify an interesting predominance of Petroleum as the main primary renewable source and in relation to primary renewable sources, there was an alternation between the Firewood (from 1970 to 1989) of hydraulic generation (1990 to 2009) and finally with the predominance of primary sources derived from sugarcane products beginning in 2002 and extending until the end of the period from 2010 to 2018.

\section{Construction of files for network analysis in the Ucinet software}

The Ucinet software demands, to build the relational matrices for the quantitative analysis of a network, a file in a proprietary format (.vna - visual network analysis) that is a repository of information for the execution of the functions present in the coding of the Ucinet software. The file is divided into two parts, first the data of the nodes (node data) where all the actors that are part of the network are described and the data of the links established between the actors (tie data).

With the execution of the ".vna" file in Ucinet, one has access to the processing of structural indicators, as in the case of this research. Initially, centrality indicators and density indicators. In this work, the ".vna" files were executed for all the years from which data were obtained, that is, from 1970 to 2018, which will be presented in the form of tables later. 
Table 5 - Primary energy production in Brazil 2010-2018

$10^{3}$ tep (toe)

\begin{tabular}{|c|c|c|c|c|c|c|c|c|c|}
\hline SOURCES & 2010 & 2011 & 2012 & 2013 & 2014 & 2015 & 2016 & 2017 & 2018 \\
\hline Non-renewable & 134.277 & 140.533 & 140.573 & 139.997 & 153.920 & 165.795 & 172.540 & 179.477 & 178.460 \\
\hline Petroleum & 106.559 & 108.976 & 107.258 & 104.762 & 116.705 & 126.127 & 130.373 & 135.907 & 134.067 \\
\hline Natural gas & 22.771 & 23.888 & 25.574 & 27.969 & 31.661 & 34.871 & 37.610 & 39.810 & 40.560 \\
\hline Steam coal & 2.104 & 2.134 & 2.517 & 3.298 & 3.059 & 2.459 & 2.636 & 1.930 & 2.005 \\
\hline Metallurgical coal & 0 & 0 & 0 & 0 & 0 & 0 & 0 & 0 & 0 \\
\hline Uranium (u308) & 1.767 & 4.209 & 3.881 & 2.375 & 681 & 512 & 0 & 0 & 0 \\
\hline $\begin{array}{l}\text { Other non- } \\
\text { renewable }\end{array}$ & 1.075 & 1.326 & 1.343 & 1.592 & 1.814 & 1.826 & 1.921 & 1.831 & 1.828 \\
\hline Renewable & 118.922 & 115.854 & 116.396 & 118.096 & 118.702 & 120.481 & 122.180 & 122.169 & 128.304 \\
\hline Hydraulic energy & 34.683 & 36.837 & 35.719 & 33.625 & 32.116 & 30.938 & 32.758 & 31.898 & 33.452 \\
\hline Firewood & 25.997 & 25.997 & 25.683 & 24.580 & 24.936 & 24.900 & 23.095 & 23.424 & 24.146 \\
\hline Sugarcane products & 48.852 & 43.270 & 45.117 & 49.304 & 49.273 & 50.424 & 50.658 & 49.725 & 50.895 \\
\hline Wind energy & 187 & 233 & 434 & 566 & 1.050 & 1.860 & 2.880 & 3.644 & 4.169 \\
\hline Solar energy & - & - & - & - & - & 5 & 7 & 72 & 298 \\
\hline Other Renewables & 9.202 & 9.518 & 9.443 & 10.021 & 11.327 & 12.354 & 12.781 & 13.406 & 15.345 \\
\hline Total & 253.198 & 256.387 & 256.969 & 258.092 & 272.622 & 286.277 & 294.720 & 301.646 & 306.764 \\
\hline
\end{tabular}

Source: EPE (2018) 
Graphs obtained for each of the years 1970 to 2018 of the study obtained with the NETDRAW visualization tool from UCINET

The network presented below, in Figure 1, was obtained using the support tool of the Ucinet software, Netdraw, which allows, from the processing of the ".vna" files, to build a graph with the visualization of the network whose data were imputed in the software and it was built according to the recommendations given by (Mollo Neto 2015), (Borgatti et al.., 2002), (Scott, 1996) and (Nascimento, 2013).

The other graphs, referring to the years 1971 to 2018 was generated in the same way, applying the same methodology, being that they are very similar presenting only the difference in the weights of the relationships between the actors and eventually the exchanges that occurred between the sources that were generated or excluded from the matrix.

Figure 1 - Image of the graph obtained from the response file obtained from the processing for the VNA for the year 1970.

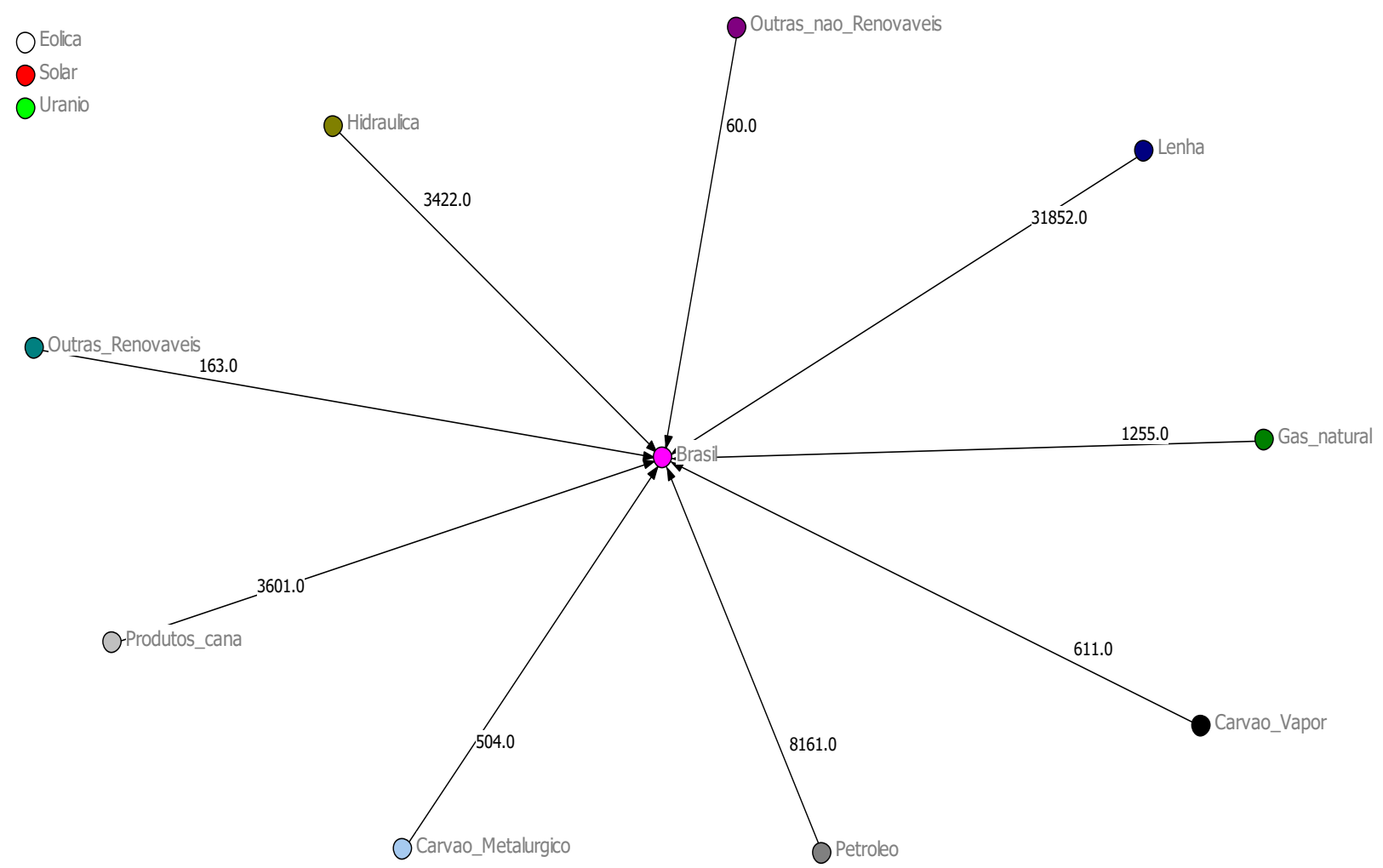

Source: Authors (2021).

Tables 6 and 7 below were assembled from the processing of all ".vna" files generated for the period from 1970 to 2018 with the Ucinet tool.

The results presented in the tool were all tabulated and served to generate the graphs in Excel, which will be presented later.

In Table 7 , it can be seen that the centrality stood out to values close to 28.3 , a fact caused by socioeconomic events that will be presented later in the discussion. In Table 7, there is also a growing behavior of densities, due to the increased contribution of sources in view of the increased demand for energy in the country. 
Research, Society and Development, v. 10, n. 10, e485101019199, 2021

(CC BY 4.0) | ISSN 2525-3409 | DOI: http://dx.doi.org/10.33448/rsd-v10i10.19199

Table 6 - Centralities obtained from the processing from 1970 to 2018.

\begin{tabular}{|c|c|c|c|c|c|}
\hline \multicolumn{4}{|c|}{ Centralidades (\%) } & \multicolumn{2}{|c|}{ Centralidades (\%) } \\
\hline VNA (ano) & Indegree & Outdegree & VNA (ano) & Indegree & Outdegree \\
\hline 1970 & 12,984 & 7,946 & 1995 & 26,903 & 6,786 \\
\hline 1971 & 18,094 & 7,520 & 1996 & 25,252 & 6,923 \\
\hline 1972 & 18,962 & 7,448 & 1997 & 24,925 & 6,951 \\
\hline 1973 & 20,986 & 7,279 & 1998 & 22,807 & 7,127 \\
\hline 1974 & 19,167 & 7,431 & 1999 & 21,552 & 7,232 \\
\hline 1975 & 18,663 & 7,473 & 2000 & 20,013 & 7,360 \\
\hline 1976 & 14,603 & 7,811 & 2001 & 19,526 & 7,401 \\
\hline 1977 & 15,601 & 7,728 & 2002 & 19,381 & 7,413 \\
\hline 1978 & 16,412 & 7,660 & 2003 & 19,828 & 7,375 \\
\hline 1979 & 17,038 & 7,608 & 2004 & 20,685 & 7,304 \\
\hline 1980 & 17,803 & 7,544 & 2005 & 19,822 & 7,376 \\
\hline 1981 & 18,899 & 7,453 & 2006 & 19,578 & 7,396 \\
\hline 1982 & 21,964 & 7,197 & 2007 & 20,539 & 7,316 \\
\hline 1983 & 23,764 & 7,047 & 2008 & 20,971 & 7,280 \\
\hline 1984 & 24,832 & 6,958 & 2009 & 19,850 & 7,374 \\
\hline 1985 & 27,079 & 6,771 & 2010 & 19,801 & 7,378 \\
\hline 1986 & 26,641 & 6,808 & 2011 & 19,606 & 7,394 \\
\hline 1987 & 28,061 & 6,689 & 2012 & 19,965 & 7,364 \\
\hline 1988 & 27,799 & 6,711 & 2013 & 20,530 & 7,317 \\
\hline 1989 & 28,060 & 6,689 & 2014 & 19,467 & 7,406 \\
\hline 1990 & 27,571 & 6,730 & 2015 & 18,915 & 7,452 \\
\hline 1991 & 28,201 & 6,678 & 2016 & 18,838 & 7,458 \\
\hline 1992 & 27,814 & 6,710 & 2017 & 18,496 & 7,486 \\
\hline 1993 & 27,552 & 6,732 & 2018 & 19,068 & 7,439 \\
\hline 1994 & 27,797 & 6,711 & 2019 & - & - \\
\hline
\end{tabular}

Source: Authors (2021). 
Research, Society and Development, v. 10, n. 10, e485101019199, 2021

(CC BY 4.0) | ISSN 2525-3409 | DOI: http://dx.doi.org/10.33448/rsd-v10i10.19199

Table 7 - Densities obtained from processing from 1970 to 2018.

\begin{tabular}{|c|c|c|c|c|c|}
\hline VNA (ano) & Densidade (Average $10^{3}$ tep (toe)) & VNA (ano) & Densidade (Average10 ${ }^{3}$ tep (toe)) & VNA (ano) & Densidade (Average10 ${ }^{3}$ tep (toe) \\
\hline 1970 & 318,135 & 1988 & 696,353 & 2006 & 1352,258 \\
\hline 1971 & 120,426 & 1989 & 711,289 & 2007 & 1434,019 \\
\hline 1972 & 332,295 & 1990 & 690,327 & 2008 & 1516,378 \\
\hline 1973 & 337,519 & 1991 & 696,705 & 2009 & 1540,942 \\
\hline 1974 & 353,968 & 1992 & 694,635 & 2010 & 1623,058 \\
\hline 1975 & 356,103 & 1993 & 702,974 & 2011 & 1643,513 \\
\hline 1976 & 358,122 & 1994 & 736,545 & 2012 & 1647,237 \\
\hline 1977 & 369,891 & 1995 & 740,359 & 2013 & 1654,436 \\
\hline 1978 & 376,141 & 1996 & 787,096 & 2014 & 1747,577 \\
\hline 1979 & 398,103 & 1997 & 835,756 & 2015 & 1835,103 \\
\hline 1980 & 425,673 & 1998 & 886,186 & 2016 & 1889,224 \\
\hline 1981 & 442,173 & 1999 & 938,526 & 2017 & 1933,635 \\
\hline 1982 & 491,801 & 2000 & 982,910 & 2018 & 1966,442 \\
\hline 1983 & 552,667 & 2001 & 1002,474 & 2019 & - \\
\hline 1984 & 636,853 & 2002 & 1117,051 & - & - \\
\hline 1985 & 685,840 & 2003 & 1177,833 & - & - \\
\hline 1986 & 675,807 & 2004 & 1219,462 & - & - \\
\hline 1987 & 707,513 & 2005 & 1285,398 & - & - \\
\hline
\end{tabular}

Source: Authors (2021)

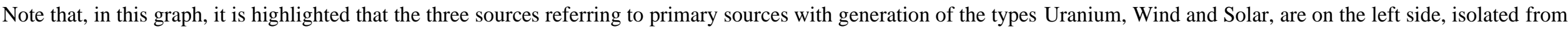
relations with Brazil, in the center, without any connection, due the fact that in this period there is no volume of contribution with generation. 
Research, Society and Development, v. 10, n. 10, e485101019199, 2021

(CC BY 4.0) | ISSN 2525-3409 | DOI: http://dx.doi.org/10.33448/rsd-v10i10.19199

\section{Graphic presentation of Centralities}

After collecting all input level centrality data for the contribution that each of the sources brings to energy production in Brazil from 1970 to 2018 according to the indications of Mollo Neto (2015); Tomaél \& Marteleto (2006); Hanneman \& Riddle (2005) and mainly by Emirbayer \& Goodwin (1994), the data were transferred to an Excel spreadsheet and the graph was generated in it, which can be viewed in Figure 2.

Next to the centralities graph, the trend line of the chosen mathematical model that best fitted the data set was plotted, according to the procedures indicated by (Bassanezi, 2002), (Biembengut \& Hein, 2003), (Costa, 2016) and (Daniel, 2016). In addition to plotting the polynomial line, the determination coefficient was indicated according to the work of Souza (2018).

Figure 2 - Image of the graph obtained with the compilation of all centrality data for the years 1970 to 2018.

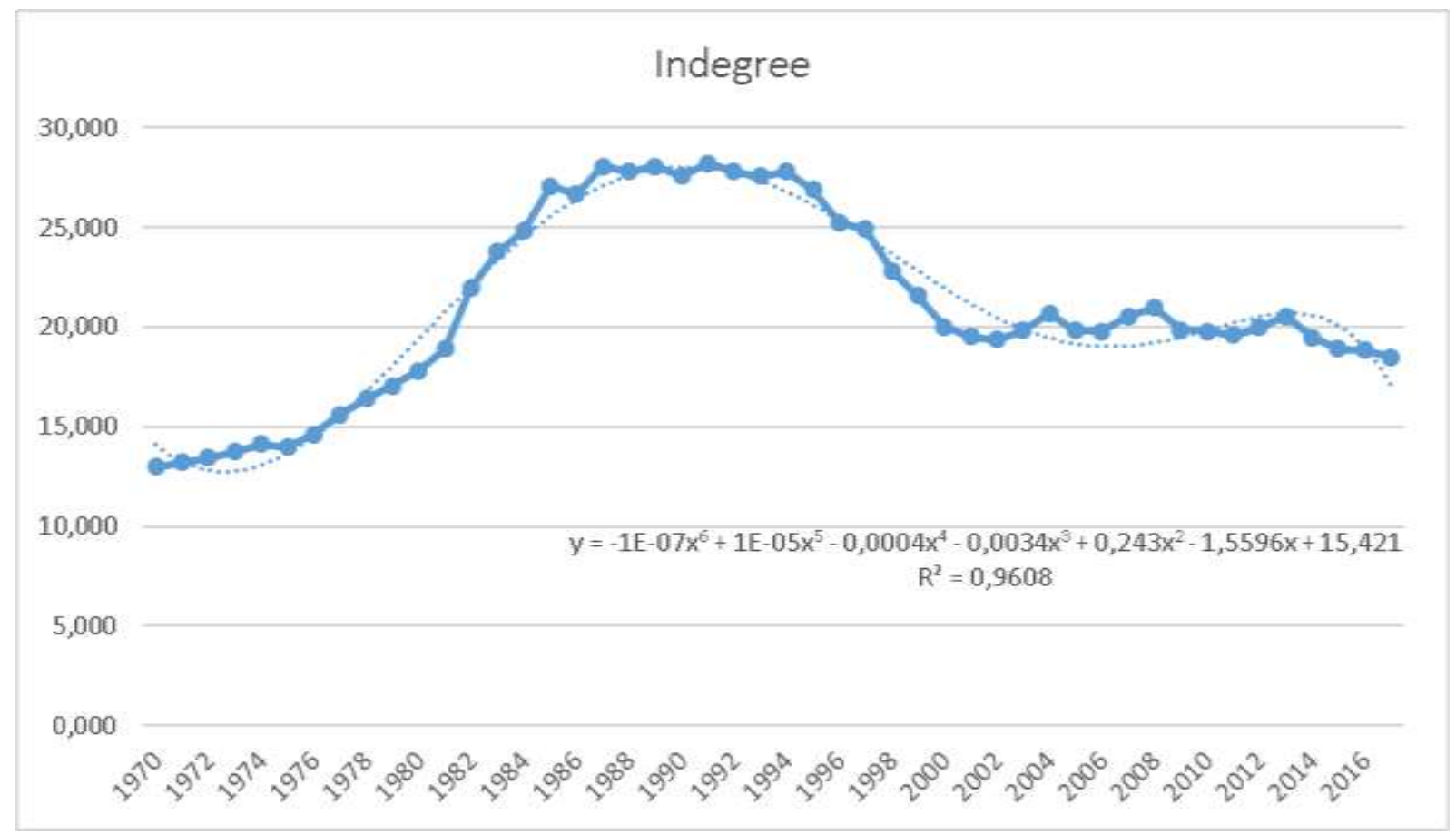

Source: Authors (2021).

As can be seen in this graph, the mathematical model that represents the variation in the centrality of primary energy production in Brazil from 1970 to 2018, is a polynomial of degree 6 that can be seen in Equation 5:

$y=-2 E-07 x^{6}+3 E-05 x^{5}-0,0014 x^{4}+0,0253 x^{3}-0,1493 x^{2}+0,535 x+14,173$

Eq. 3

$$
R^{2}=0,9608
$$

The polynomial found, has the conformation indicated by Daniel (2016).

The determination coefficient found was $\mathbf{0 . 9 6 0 8}$.

This indicates that the model represents well the reality of the data excursion, as it is close to 1 as indicated by Mollo Neto et al. (2014). 
Research, Society and Development, v. 10, n. 10, e485101019199, 2021

(CC BY 4.0) | ISSN 2525-3409 | DOI: http://dx.doi.org/10.33448/rsd-v10i10.19199

\section{Graphic presentation of Densities}

Then, the same procedure was performed for the values referring to the densities of the networks in the period.

From the annotated values for all densities found for the energy production graphs in Brazil from 1970 to 2018, applying the procedure determined by the authors Masquietto et al. (2011), it was possible to assemble the graph in Figure 3 in the Excel tool.

Along with the graph of densities, the trend line of the chosen mathematical model that best fit the data set was plotted, according to the procedures indicated by (Bassanezi, 2002), (Biembengut \& Hein, 2003), (Costa, 2016) and (Daniel, 2016). In addition to plotting the polynomial line, the determination coefficient $\left(\mathrm{R}^{2}\right)$ was also indicated according to the work of Souza, (2018).

The growing trend of network density is visible and allows us to understand that, due to the increase in demand, energy sources are pressured to increase the volume of production, which means that those that gain predominance have their values increased, a fact that elevates the centrality of the network as a whole.

Therefore, with the increase in demand, density increases in line with growth similar to GDP and HDI.

Figure 3 - Image of the graph obtained with the compilation of all density data for the years 1970 to 2018.

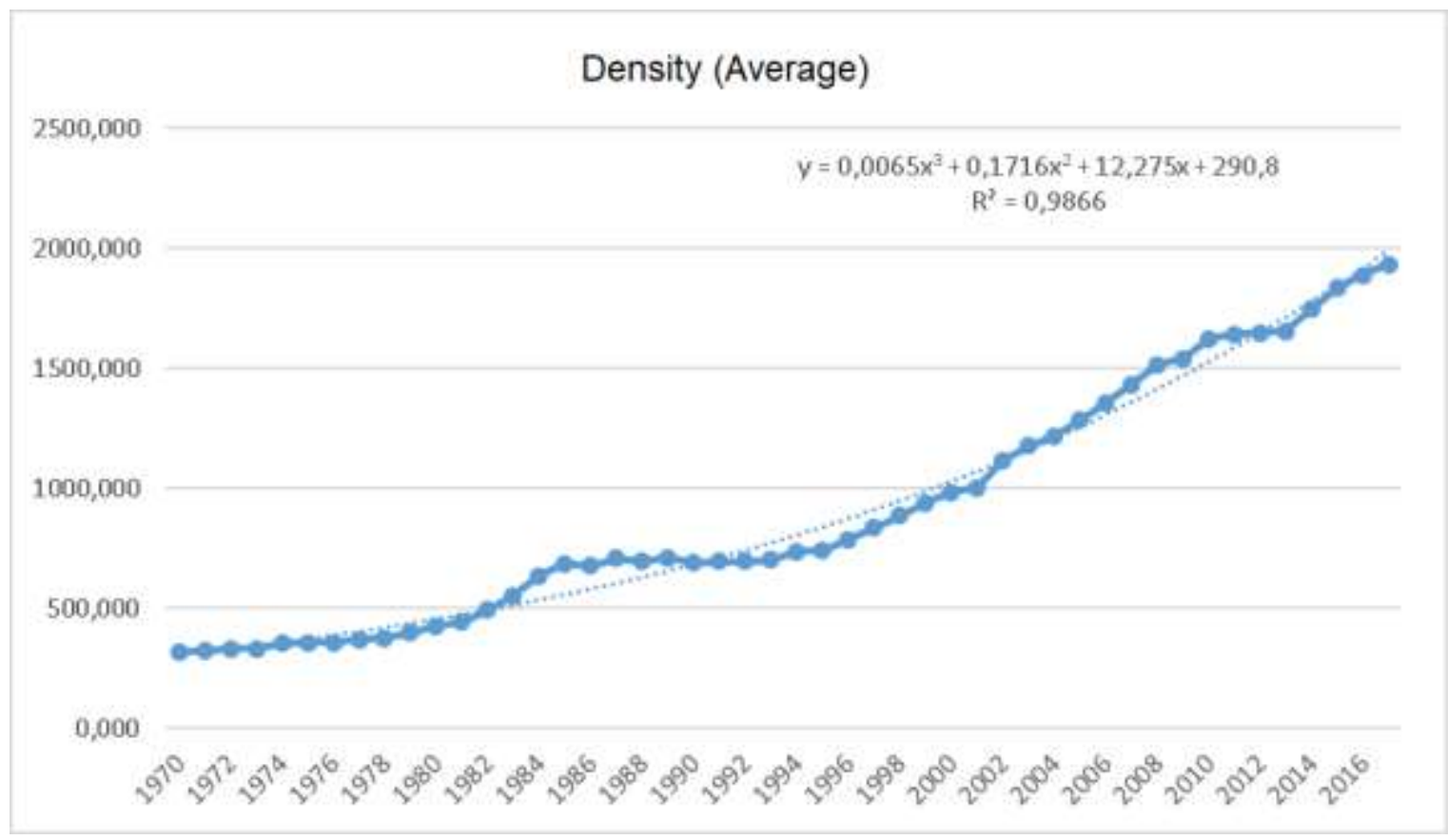

Source: Authors (2021).

As can also be seen in this graph, the mathematical model that represents the variation in the density of primary energy production in Brazil from 1970 to 2017 is a polynomial of degree 3 that can be seen in Equation 6:

$y=0,0064 x 3+0,1749 x 2+12,176 x+291,69$

Eq. 4

$$
R^{2}=0,9866
$$

The polynomial found, has the conformation indicated by (Daniel, 2016). 
The determination coefficient found for this polynomial was $\mathbf{0 . 9 8 6 6}$. This indicates that the model represents well the reality of the data excursion, as it is close to 1 as indicated by Mollo Neto et al. (2014).

In the graph in Figure 2, we can highlight some interesting temporal periods, where peaks of centrality stand out, where, according to the data obtained from Table 6, they are due to socioeconomic movements.

Thus, a search was performed and the following points for discussion were obtained from the bibliography:

We see the first peak of centrality in 1973, which results from movements that, according to Macarini (2005) are related to economic policy during Emílio Garrastazu Médici's government, a period that became known by the official description of the cyclical boom then underway as if it was a developmental cycle capable of extending for decades, projecting to overcome the backwardness, but the same author points out that the hallmark of monetary policy during the "miracle" was its expansionist character and, at least in 1970, its execution reflected some caution: the real expansion of the money supply did not exceed 6\%, by far the most modest performance observed from 1967 to 1973 and adds that in 1972-1973, an international and domestic economic scenario of intense growth is combined, which generates difficulties for the conduct of economic policy; this, moreover, expresses in its formulation ambitions that deepen the difficulties.

It is therefore convenient, according to Macarini (2005), to treat this subperiod separately, considering it a new (terminal) phase of the "miracle" economic policy - insofar as some new constraints overlap.

In the second period observed, we have the time range from 1976 to 1982 with emphasis on the centralities, and, as described in the work of Bellingieri (2005), it was the period corresponding to the end of the term of President Ernesto Geisel (1974 to 1979) and the growth as it was most likely due to the launch of the Second National Development Plan (II PNPD), whose main objective was to promote an adjustment in the long-term supply structure while maintaining growth.

According to reports by Marangoni (2012), in his study “1980s, lost or won decade?" The author reports that The 1980s were marked by a deep economic crisis and the end of the dictatorship (1964-85). He adds that "If we use a flexible metric, we can say that the year 1980, in the scope of the economy, marks the end of the long national-developmental cycle, which started in 1930". Also according to Marangoni (2012), there were internal and external constraints in interrupting that cycle. The arrival of the 1980s signaled the end of time for world capitalism and the unfeasibility of the developmental project in peripheral countries. In advanced economies, the years of continuous growth, between 1945 and 1975, declined.

In addition, according to the author, the Organization of the Petroleum Producing Countries (OPEC) decided to reorganize the international fuel market, promoting two increases in the international prices of the product, in 1973 and 1979. Oil prices increased 12 times in this interval, creating serious difficulties for importing countries, including Brazil.

The crisis would lead the last government of the dictatorship, headed by General João Figueiredo (1979-85), to take drastic measures. The initial objective was to stop the appreciation of the national currency noted in previous years, to encourage exports and to face the increase in the current account deficit (Marangoni, 2012).

Thus, in 1981, the country entered a recession that would last until the second half of 1982, exactly as reflected in the graph showing the centralities and highlighting the stagnation for this period with the interruption of growth.

Bresser-Pereira - economist, political scientist, social scientist, business administrator, and Brazilian lawyer and who was also Minister of Finance of Brazil (1987), said that "The 1980s were lost from the economic point of view" (Marangoni, 2012).

The 1980s were marked by stagnating activity levels, profound macroeconomic imbalances and, in particular, virtual hyperinflation. In the 1980-1993 period, the average growth rate of the Brazilian economy was very low, of only $2.1 \%$ per year, causing the country to register a stagnation in GDP per capita between 1980 and 1993, as seen in the centralities graph.

This was also highlighted by the work of Andrada (2017), who says that "In economic historiography, the term" lost 
decade "refers to the period between 1981 and 1993 when Brazil's per capita GDP shrank in absolute terms. In 1981 the GDP per capita was US\$ 8,300, while in 1993 it fell by US\$ 8.1”. According to the author, this means, in a simple and objective way, that in 1993 we were poorer than we were in 1981.

These movements can be directly related to the sharp drop in the centralities obtained in the centralities graph in the period between 1994 and 2002, where a strong drop is seen.

Andrada (2017) points out that, during this period, Brazil's problems were believed to be two: public debt (internal and external) and inflation. Solved these problems, we would grow again. He reinforces saying that in 1994 the "Real Plan" was implemented, and during the FHC years, the issue of inflation was resolved. The IPCA, which dropped from an incredible $2,477.15 \%$ in 1993 , dropped to $22.41 \%$ in 1995 , falling below one digit in 1996.

The performance of our economy during the FHC years (1995-2002) was negligible (Andrada, 2017).

From 2002 to 2004, there was a slight increase or recovery in the economy, also possible to be identified in the graph. This fact was highlighted by Andrada (2017) who points out that "During the Lula government (2003-2010) Brazil rehearsed a resumption of growth. Lula delivered the country with a GDP per capita of just over $\$ 11,000$.

An increase of $20 \%$ in relation to what he had received, while in the FHC government the increase was only $4.4 \%$. According to the same author, this was the time of the "spectacle of growth", of the "new middle class". Andrada (2017) concludes by saying, about this period, that we had for the first time in the history of the country two consecutive years of GDP decline and 2017 was projected to fall by more than $3 \%$ and by almost $2 \%$ for the year 2018 .

With the data presented, it was possible to characterize the evolution, throughout history, of primary energy production in Brazil, predominantly led by oil and firewood until 1995, currently, the consumption of firewood still remains high, being the fourth source of energy that most contributed to primary energy production in Brazil in 2018.

With regard to the oil sector, in 1990, oil became the most produced primary energy source in Brazil. Essentially, oil production is under the control of Petrobrás, which has invested in technology to explore deposits.

In particular, the discovery, in 1984, of the Marlin Oil field was an important historical landmark, increasing the oil supply.

In 2015, it is possible to observe a significant increase in the contribution of natural gas to the energy matrix, a byproduct of oil extraction. Historically, the data reveal a three-fold increase in oil and natural gas in 2010 compared to the 1970s. Currently, natural gas contributed $12.5 \%$ to the energy matrix (BEN, 2019).

The Brazilian energy potential is also highlighted by the production of energy from sugarcane products, in 2018 ethanol production, for example, increased by $45.2 \%$ in relation to the previous cycle according to Conab (2019), evidenced in the graph of 2018, where sugarcane products were the second source that contributed most to the production of primary energy.

The sources of firewood and coal decreased their contribution to the supply of primary energy with the implementation of the Pro Alcohol program, due to the oil crisis in the mid-1970s.

In relation to nuclear energy, the first contribution of this energy source in Brazil occurred in 1982 with the inauguration of "Usina Angra I", interrupting its operation in 1991, and resuming its continuous production in 2000, however, since 2015 there is no production of primary energy of the nuclear source in the Brazilian energy matrix.

An important result, as already mentioned, was observed with the evolution and of oil as a non-renewable primary source offer and the alternation of offers from non-renewable sources that, presented an evolution in the early 1970s until the end of the decade in 1979 with the predominance of firewood, passing to the generation of hydraulic energy that was the most important for two decades from 1980 to 2009, a fact that reflects the inauguration on May 5, 1984, of the start of operation of 
Research, Society and Development, v. 10, n. 10, e485101019199, 2021

(CC BY 4.0) | ISSN 2525-3409 | DOI: http://dx.doi.org/10.33448/rsd-v10i10.19199

the first generating unit of the Itaipu plant and thereafter its capacity building over the indicated two decades.

After this period, a new exchange was observed, ending the hydraulic modality for being supplanted by-products derived from sugarcane, which extends until 2018. This fact draws attention and allows us to infer that the investments made in this energy sector were very effective and contribute significantly to the national energy matrix.

In the period from 2010 to 2018 , the share of supply from primary renewable sources, in percentage terms, is no longer so distant from the share of offers from non-renewable primary sources, almost even dividing availability for the composition of the matrix. These findings are in line with the data provided by (EPE, 2018).

\section{Conclusion}

With the development of this research, it was possible through data surveys to obtain the totals of primary energy generated in the country within the period from 1970 to 2018 for the various sources that contribute to the Brazilian matrix.

It was possible, with the application of the computational tool UCINET and its visualization module Netdraw, to determine the corresponding relational matrices and structural indicators of centrality and density of the primary energy supply in Brazil from 1970 to 2018, as well as building the graphs for each one obtained with the visualization tool.

Based on the results obtained and the new prospecting of literature on the economy of Brazil in the period between the years 1970 to 2018, it became possible to discuss the movements carried out by formulators of public policies based on data and experience of the national scenario that culminated in a reduction of investments in the sector, even though the demand is always growing, but remains linked to the results of small increases in GDP and HDI in the period surveyed.

The general objective of the research was to document the scenario of the behavior of primary energy production in Brazil to elaborate the mathematical models that represent the variation of the structural indicators of the network constituted in the period from 1970 to 2018, a fact that was confirmed with the generation of the mathematical models extracted from the centrality and density graphs generated with the support of the Ucinet and Netdraw tools.

As recommendations for the continuity of the work, the evolution evaluation of the centralities and densities for the same primary energy sources in Brazil can be considered, in order to ascertain whether, with the change of government that took place in 2019, through the new public policies adopted, there will be a turning point for the abrupt downward trend was seen in the period from 2002 to 2018 to be stopped and our country will find itself in a new period of growth, which would result in new investments in infrastructure, leading to further expansion more densities, collaborating in order to improve the results of GDP and HDI.

Finally, considering possible future research, it would be very convenient to monitor the evolution of the densities of the networks that will be formed from 2020, and also the evolution of densities, in order to detect the impacts of the Coronavirus pandemic (COVID-19) and the public policies that were adopted in its fight that reflected in the supply of primary and secondary energies in Brazil.

\section{Acknowledgments}

This work was supported by the Brazilian National Council for Scientific and Technological Development - CNPq and also by the São Paulo Research Foundation - FAPESP. 
Research, Society and Development, v. 10, n. 10, e485101019199, 2021 (CC BY 4.0) | ISSN 2525-3409 | DOI: http://dx.doi.org/10.33448/rsd-v10i10.19199

\section{References}

Andrada, A. (2017). Uma breve história da economia brasileira (1948-2018). https://www.huffpostbrasil.com/alexandre-andrada/uma-breve-historia-daeconomia-brasileira-1948-2018_b_8720394.html

ANEEL. (2008). Atlas de Energia Elétrica do Brasil. http://www2.aneel.gov.br/arquivos/PDF/atlas_par2_cap5.pdf

ANEEL. (2019). BIG - Banco de Informações de Geração. http://www2.aneel.gov.br/aplicacoes/capacidadebrasil/capacidadebrasil.cfm

Bassanezi, R. (2002). Ensino - aprendizagem com Modelagem matemática. (3a ed.), Ed. Contexto.

Bellingieri, J. C. (2005). A economia no período militar (1964-1984): crescimento com endividamento. Revista Online Fabibe. 1(1), 1-13.

BEN. (2019) Balanço Energético Nacional: Relatório Síntese BEN 2019 Ano Base 2018. Rio de Janeiro: EPE. http://www.epe.gov.br/sites-pt/publicacoesdados-abertos/publicacoes/PublicacoesArquivos/publicacao-377/topico-470/Relat\%C3\%B3rio\%20S\%C3\%ADntese\%20B EN\%202019\%20An o\%20Base\% 202018.pdf

Biembengut, M. S. \& Hein, N. (2003). Modelagem Matemática no ensino. (3a ed.), Contexto.

Borgatti, S. P., Everett, M. G. \& Freenan, L. C. (2002). Ucinet 6 for Windows: Software for Social Network Analysis. Analytic Technologies.

British Petroleum, B. P. (2018). British Petroleum Statistical Review of World Energy. https://www.bp.com/content/dam/bp/business-sites/en/global/co rporate/pd fs/ener gy-econ omics/statis tical-review/bp-stats-review-2018-full-report.pdf

Carley, K. M., Desner, J., Reminga, J. \& Maksim, T. (2007). Toward an Interoperable Dynamic Network Analysis Toolkit. Decision Support Systems, 43(4), $1324-47$.

CONAB, (2019). Conab Produção de etanol no Brasil mantém recorde com 33,14 bilhões de litros. Companhia Nacional de Abastecimento. https://www.conab.gov.br/ultimas-noticias/2859-producao-de-etanol-no-brasil-mantem-recorde-e-alcanca-33-58-bilhoes-de-litros

Conway, F. (1962). A First Course in Mathematical Statistics. By C. E. Weatherburn. Pp. Xii + 277. 1961. 18s. 6d. (Cambridge University Press). The Mathematical Gazette, 46, (356), 158-158.

Costa, F. de A. (2016). Ensino matemática por meio da modelagem matemática. Ensino da Matemática em Debate. 3, (1), 58-69.

Creswell, J. W. (2007). Projeto de Pesquisa: Métodos qualitativo, quantitativo e misto. (2a ed.), Artmed.

Daniel, D. (2016). Modelagem por Polinômios no Ensino Médio. 2016. Unicamp, 127 f. Dissertação (mestrado) Instituto de Matemática, Estatística e Computação Científica. Universidade Estadual de Campinas. Campinas.

Dehmer, M., Emmert-Streib, F. \& Shi, Y.(2017). Quantitative Graph Theory: A New Branch of Graph Theory and Network Science. Information Sciences, $418-419,(1), 575-580$.

Demirel, Y. (2012). Energy and Energy Types. In: Demirel, Y. (Ed.). Energy. Ed. Springer London.

Emirbayer, M. \& Goodwin, J. (1994). Network Analysis, Culture, and the Problem of Agency. American Journal of Sociology. 99, (6), 1411-1454.

EPE. (2018). World Energy Outlook 2018. Empresa de Pesquisa Energética - EPE. http://www.epe.gov.br/sites-pt/sala-de-imprensa/noticias/Documents/1 2\%20April\%20_\%20EPE\%20WEO\%20launch_Clean\%20(002).pdf

Firjan. (2019). Anuário da Indústria de Petróleo no Rio de Janeiro Panorama 2019. Firjan - Federação das Indústrias do Estado do Rio de Janeiro. https://www.firjan.com.br/publicacoes/publicacoes-de-economia/anuario-petroleo-e-gas.htm

Hanneman, R. \& Riddle, M. (2005). Social Network Data. In: Introduction_to_Social_Network_Methods. University of California, Riverside: Department of Sociology.

Izquierdo, L. R. \& Hanneman, R. A. (2006). Introduction to the Formal Analysis of Social Networks Using Mathematica. Published in digital form, Burgos, Spain. http://luis.izqui.org/papers/Izquierdo_Hanneman_2006-version2.pdf.

Koche, J. C. (2011). Fundamentos de metodologia científica. Ed. Vozes. http://www.brunovivas.com/wp-content/uploads/sites/10/2018/07/K\%C3\%B6cheJos\%C3\%A9-Carlos0D0AFundamentos-de-metodologia-cient\%C3\%ADfica-_teoria-da0D0Aci\%C3\%AAncia-e-inicia\%C3\%A7\%C3\%A3o-\%C3\%A0pesquisa.pdf

Levine, S. S. \& Kurzban, R. (2006). Explaining Clustering in Social Networks: Towards an Evolutionary Theory of Cascading Benefits. Managerial and Decision Economics, 27, (2-3), 173-187.

Ludke, M. \& Andre, M. E. D. A. (2013). Pesquisas em educação: uma abordagem qualitativa. Ed. E.P.U.

Macarini, J. P. (2005). A política econômica do governo Médici: 1970-1973. Nova Economia, 15, (3), 53-92.

Mahalingam, B. \& Orman, W. H. (2018). GDP, and Energy Consumption: A Panel Analysis of the US. Applied Energy, 213, (1), 208-218.

Makagon, M. M., McCowan, B. \& Mench, J. A. (2012). How Can Social Network Analysis Contribute to Social Behavior Research in Applied Ethology? Applied Animal Behaviour Science, 138, (3-4), 152-161. 
Research, Society and Development, v. 10, n. 10, e485101019199, 2021 (CC BY 4.0) | ISSN 2525-3409 | DOI: http://dx.doi.org/10.33448/rsd-v10i10.19199

Marangoni, G. (2012). IPEA - Instituto de Pesquisa Aplicada. Anos 1980, década perdida ou ganha? Revista de informações e debates. 72, (1), 1-2. http://www.ipea.gov.br/desafios/index.php?option=com_content\&id=2759:catid=28\&Itemid=23

Masquietto, C. D., Sacomano Neto, M. \& Giuliani, A. C.(2011). Centrality and Density in Interfirm Networks: A Study of an Ethanol Local Productive Arrangement. Review of Administration and Innovation - RAI, 8, (1), 122-147.

Mollo Neto, M. (2015). Análise de Redes. In: REIS, J. G. M. (Ed.). Qualidade em Redes de Suprimentos: a qualidade aplicada ao supply chain management. Ed. Atlas.

Mollo Neto, M., Carreira Junior, E. F., Gonçalves Junior, O. E., Romano, S. M. V. \& Morales, V. (2014). Análise de redes para prospecção de indicadores da produção de biodiesel no brasil. Energia na agricultura, 29, (4), 306-316.

Mollo Neto, M., Nääs, I.A., Vendrametto, O. \& Okano, M.T. (2010). Quantitative analysis supported in sna of the production milk chain in Brazil, CIGR XVIIth World Congress - Québec City, Canada , 1, (1), 1-9.

Nascimento, C. S. D. (2013). PANDORA - Uma Ferramenta para Visualização Incremental e Análise de Redes Sociais Acadêmicas. Universidade Federal do Rio Grande do Sul, Dissertação (mestrado) Programa de Pós-Graduação em Computação - Porto Alegre. https://lume.ufrgs.br/bitstream/handle/10183/67851/000874023.pdf?sequence=1\&isAllowed=y

Nogueira, L. P. P., Lucena, A. F. P., Rathmann, R., Rochedo, P. R. R., Szklo, A. \& Schaeffer, R. (2014). Will Thermal Power Plants with CCS Play a Role in Brazil's Future Electric Power Generation? International Journal of Greenhouse Gas Control, 24, (1), 115-123

Ouedraogo, N. S. (2013). Energy Consumption, and Economic Growth: Evidence from the Economic Community of West African States (ECOWAS). Energy Economics, 36, (1), 637-647.

Peng, H., Bao, M., LI, J., Bhuiyan, M. Z. A., Liu, Y., He, Y. \& Yang, E. (2018). Incremental Term Representation Learning for Social Network Analysis. Future Generation Computer Systems, 86, (1), 1503-1512.

Pereira, A. S., Shitsuka, D. M., Parreira, F. J. \& Shitsuka, R. (2018). Metodologia da pesquisa cientifica. UFSM. https://repositorio.ufsm.br/bitstream/hand le/1/15824/Lic_Computacao_Metodologia-Pesquisa-Cientifica.pdf?sequence=1

Ren 21. (2019). Renewables 2019 global status report. France: Frankfurt School UNEP Collaborating Centre for Climate \& Sustainable Energy Finance, Bloomberg NEF and UN Environment. Ed. REN21 Secretariat. https://www.ren21.net/wp-content/uploads/2019/05/gsr_2019_full_report_en.pdf

Rossoni, L., Silva, A. J. H. \& Ferreira Júnior, I. (2008). Aspectos estruturais da cooperação entre pesquisadores no campo de administração pública e gestão social: análise das redes entre instituições no Brasil. Revista de Administração Pública, 42, (6), 1041-1067.

Scott, J. (1996). Software Review : A Toolkit for Social Network Analysis. Acta Sociologica, 39, (2), $211-216$.

Silveira, D. (2019). Crise econômica freia consumo de energia primária no Brasil, aponta Firjan. https://g1.globo.com/economia/noticia/2019/08/07/criseeconomica-freia-consumo-de-energia-primaria-no-brasil-aponta-firjan.ghtml

Sorrell, S. (2015). Reducing Energy Demand: A Review of Issues, Challenges, and Approaches. Renewable and Sustainable Energy Reviews, 47, (1), 74-82.

Souza, F. B. de. (2018). Blog 2 Engenheiros: Como obter a equação de regressão de um conjunto de dados no Excel? https://2engenheiros.com/2018/1 2/18/equacao-regressao-excel

Stokman, F. N. (2001). Networks: Social. In: Semelser N.J., B. P. B. (Ed.). International Encyclopedia of the Social \& Behavioral Sciences. Ed. Elsevier.

Tainter, J. A. (2011). Energy, Complexity, and Sustainability: A Historical Perspective. Environmental Innovation and Societal Transitions, 1, (1), 89-95.

Tolmasquim, M. T., Guerreiro, A. \& Gorini, R. (2007). Matriz energética brasileira: uma prospectiva. Novos Estudos - CEBRAP, 79, (1), 47-69.

Tomaél, M. I. \& Marteleto, R. M. (2006). Redes sociais: posições dos atores no fluxo da informação. Encontros Bibli: revista eletrônica de biblioteconomia e ciência da informação, 11, (1), 75-91.

Yin, R. K. (2015). O estudo de caso. Ed. Bookman. 